\title{
Financial Distress and Bankruptcy Prediction in Conditions of Slovak Republic
}

\author{
Filip Rebetak ${ }^{1, *}$, and Viera Bartosova ${ }^{1}$ \\ ${ }^{1}$ University of Zilina, Faculty of Operation and Economics of Transport and Communications, \\ Department of Economics, Univerzitna 1, 01026 Zilina, Slovakia
}

\begin{abstract}
.
Research background: Prediction of bankruptcy has an important place in financial analysis of an organization in the globalized economy. Ever since the first publication of a paper on bankruptcy prediction in 1932, the field of bankruptcy prediction was attracting researchers and scholars internationally. Over the years, there have been a great many models conceived in many different countries, such as Altman's Z score or Ohlson's model for use for managers and investors to assess the financial position of a company. Globalization in last few decades has made it even more important for all stakeholders involved to know the financial shape of the company and predict the possibility of bankruptcy.

Purpose of the article: We aim in this article to examine the financial distress and bankruptcy prediction models used or developed for Slovakia to provide an overview of possibilities adjusted to specific conditions of the Slovak Republic in context of globalization. We will also look at the possibility of use of these prediction models for assessing financial status of non-profit organizations in the Slovak Republic.

Methods: We will use analysis and synthesis of current research and theoretical background to compare existing models and their use.

Findings \& Value added: We hope to contribute with this paper to the theoretical knowledge in this field by summarizing and comparing existing models used.
\end{abstract}

Keywords: financial distress; bankruptcy prediction; bankruptcy models

JEL Classification: $M 20, M 21$, M40

\section{Introduction}

Prediction of bankruptcy has an important place in financial analysis of an organization. Ever since the first publication of a paper on bankruptcy prediction in 1932, the field of bankruptcy prediction was attracting researchers and scholars around the world. Over the years, there have been a great many models conceived in many different countries, such as Altman's $Z$ score or Ohlson's model. The main aim of their scientific work was primarily to create models

* Corresponding author: filip.rebetak@,fpedas.uniza.sk 
that would be able to predict with a sufficient degree of probability the future development of the company in advance. [1] Globalization in last few decades has made it even more important for all stakeholders involved to know the financial shape of the company and predict the possibility of bankruptcy. The market economy is a dynamic space designated by the emergence but also the extinction of many business entities. The financial problems of one business entity may adversely affect business entities that work closely with it. [2] Many studies were also dedicated to the verification of such models. Some of the research brings up the limitations that these models have. Among them are the usefulness of their use for predicting bankruptcy in different industries and countries.

Every prediction model is constructed on data from a specific country or group of countries, no matter what method is used. Some of the models are even based on industry specific data. This data is based on specific conditions in the country, its economic development, history of its capital markets. Therefore, their applicability to different countries might be limited and country or industry specific models should be used with caution. Models developed in the specific economic sector highly outperform the prediction ability of other models either developed in the same country or abroad. [3] In case of Slovakia, some of foreign models are not usable due to the state of Slovak capital market. Kliestik et al. [4] identified that different countries prefer different financial rations in developing models of prediction of financial distress with differences arising as a consequence of common changing political, market and economic conditions. Kral et al. [5] also assessed the use of financial ratios.

Slovak Republic lacks general prediction models that are accepted. [6] However, as we will see in the later part of the article, it is a subject of current research among academics in Slovakia.

We aim in this article to present and examine the financial distress and bankruptcy prediction models used or developed for Slovakia.

\section{Methodology}

We aim in this article to examine the financial distress and bankruptcy prediction models used or developed for Slovakia to provide an overview of possibilities adjusted to specific conditions of the Slovak Republic in context of globalization. We will also look at the possibility of use of these prediction models for assessing financial status of non-profit organizations in the Slovak Republic. To achieve that aim, we looked through the scientific databases such as Web of Science and Google Scholar to find articles concerning bankruptcy prediction in the conditions of Slovak Republic. We analyzed those articles to find models used for bankruptcy prediction by their authors or models mentioned with claims of their use in Slovakia and synthesized the results for this article.

\section{Bankruptcy prediction models}

After going through the current research on the topic of bankruptcy prediction we have chosen the following models as the most used and discussed in scientific literature in conditions of Slovak Republic.

\subsection{Altman}

One of the most prominent models used in Slovakia is the Altman model from 1968. Altman developed bankruptcy prediction model based on multivariate discriminant analysis (MDA) 
based on 5 out of 22 potential financial indicators. The discriminatory function is as follows [7]:

where:

$$
Z=1,2 X 1+1,4 X 2+3,3 X 3+0,6 X 4+1 X 5
$$

$\mathrm{X} 1 \quad=$ Working Capital / Total Assets

$\mathrm{X} 2=$ Retained Profit $/$ Total Assets

$\mathrm{X} 3=$ Earnings before interest and taxes $/$ Total Assets

$\mathrm{X} 4=$ Market value of equity / Foreign capital

$\mathrm{X} 5 \quad=$ Sales $/$ Total Assets

The evaluation goes as follows:

$\begin{array}{ll}1,81<=Z & \text { threat of bankruptcy } \\ 1,81<Z<=2,90 & \text { grey zone } \\ 2,90<Z & \text { healthy }\end{array}$

The first Altman model in 1968 was for publicly traded companies. One of the later variants in 1983 was developed for companies that are not publicly traded, which is a more applicable to the conditions of the Slovak Republic. The discriminatory function for the 1983 variant is as follows:

$$
Z 1983=0,717 X 1+0,847 X 2+3,107 X 3+0,42 X 4+0,998 X 5
$$

Altman models where used for example in research by Delina, Packova [8], Gavurova, Packova, Misankova, Smrcka, [9], Kovacova, Kliestikova [10], Camska [11], Misankova, Zvarikova, Kliestikova, [12] and many more. Adamko, Svabova [13] studied prediction ability of Global Altman's model on Slovak companies. Rybarova, Braunova, Jantosova [14] used Altman's model on a specific sector of economy, namely construction industry in Slovakia.

\subsection{IN 05}

IN05 is one of a family of indexes developed in Czech Republic by Neumaierova, Neumaier. It respects conditions in Czech Republic and IN05 is the latest from the family thus it is the one currently most used. The IN05 index is as follows: [15]

$$
I N 05=0.13 \times A / L+0.04 \times E B I T / I+3.97 \times E B I T / A+0.21 \times R / A+0.09 \times C A / S T L
$$

where

$$
\begin{array}{ll}
\text { EBIT } & =\text { Earnings before Interest and Tax } \\
\text { A } & =\text { Total Assets } \\
\text { L } & =\text { Total Liabilities } \\
\text { I } & =\text { Interest } \\
\text { R } & =\text { Revenues } \\
\text { CA } & =\text { Current Assets } \\
\text { STL } & =\text { Short-term Liabilities. }
\end{array}
$$

The evaluation goes as follows: (Neumaierova, Neumaier, 2005) IN $<0,9 \quad$ unhealthy 


$$
\begin{array}{ll}
0,9<\mathrm{IN}<1,6 & \text { grey zone } \\
1,6<\mathrm{IN} & \text { value creation }
\end{array}
$$

IN05 is also a widely used model in the research focused on prediction of bankruptcy of Slovak companies. We can find it in articles by Delina, Packova [8]; Gavurova, Packova, Misankova, Smrcka [9]; Misankova, Zvarikova, Kliestikova [12] and more.

\subsection{CH-index}

$\mathrm{CH}$-index is one of a few domestically developed models which was presented by Chrastinova in 1998 and developed for use mainly in agricultural sector, as it was developed on companies from this sector. It is based on discriminant analysis. [16]

Discriminant function for $\mathrm{CH}-$ index is as follows:

$$
C H=0.37 \times E / A+0.25 \times E / S+0.21 \times C F / S T L-0.1 \times(S T L \times 365) / C F-0.07 \times D / A
$$

$$
\begin{array}{ll}
\text { where } & \\
\text { E } & =\text { Earnings } \\
\text { A } & =\text { Total Assets } \\
\text { S } & =\text { Sales } \\
\text { CF } & =\text { Cash Flow } \\
\text { STL } & =\text { Short-term Liabilities } \\
\text { D } & =\text { Debts. }
\end{array}
$$

The interpretation of the Ch-index is as follows: [16]

$$
\begin{array}{ll}
\mathrm{CH}<-5 & \text { unhealthy } \\
-5<\mathrm{CH}<2.5 & \text { grey zone } \\
2.5<\mathrm{CH} & \text { healthy }
\end{array}
$$

CH-Index is also used widely, albeit less than Altman or IN05. Karpac, Bartosova [17]; Durica, Svabova [18] or Camska [11] used it in their research for example.

\subsection{G-index}

Another model developed in Slovakia and also for the use in mainly agricultural companies is G-index, developed by L. Gurcik in 2002. Its discriminant function is as follows: [19]

$$
G=3.412 \times R E / A+2.226 \times E B T / A+3.27 \times E B T / A+3.149 \times C F / A-2.063 \times I N V / R
$$

$$
\begin{array}{ll}
\text { where } & \\
\mathrm{RE} & =\text { Retained Earnings } \\
\mathrm{A} & =\text { Total Assets } \\
\mathrm{EBT} & =\text { Earnings before Taxes } \\
\mathrm{R} & =\text { Revenues } \\
\mathrm{CF} & =\text { Cash Flow } \\
\mathrm{INV} & =\text { Inventories }
\end{array}
$$

The interpretation of G-index is as follows: [19]

$$
\begin{array}{ll}
\mathrm{G}<-0,6 & \text { unhealthy } \\
-0,6<\mathrm{G}<1,8 & \text { grey zone } \\
1,8<\mathrm{G} & \text { healthy }
\end{array}
$$


G-Index is used similarly to CH-Index because of their similarity being based on agricultural companies. We can find it for examples in articles by Karpac, Bartosova [17]; Durica, Svabova [18] or Camska [11].

\subsection{Gulka model}

The Gulka's model is a relatively new model that was obtained using a logistic regression method on a sample of 120854 Slovak companies. The math entry is as follows [20]:

$$
p=\frac{e^{0.0216-0.6131 X 1-0.0068 X 2-0.0296 X 3-0.0011 X 4+0.0240 X 5}}{1+e^{0.0216-0.6131 X 1-0.0068 X 2-0.0296 X 3-0.0011 X 4+0.0240 X 5}}
$$

where

$\mathrm{X} 1=$ Quick Ratio $=($ Financial accounts $/$ (Short-term liabilities + Short-term financial borrowings + Current bank loans))

$\mathrm{X} 2=$ Working Capital Turnover $=(($ Revenue from sold goods + Manufacture $) /$ Working capital; while WC is Current assets - Short-term liabilities - Short-term financial borrowings - Current bank loans)

X3 = Financial Accounts Ratio (in \%) $=($ Financial accounts $/$ Total Assets $)$

$\mathrm{X} 4=$ Self-financing Ratio (in \%) $=($ Equity / Total Assets)

$\mathrm{X} 5=$ Credit load (in \%) $=(($ Fixed Bank loans + Short-term financial accommodations) / Total Assets)

$\mathrm{X} 6=$ Share of liabilities to state institutions (in \% $)=(($ Payables from social insurance + Tax liabilities and grants) / Total Assets)

X7 $=$ Return on Assets from the perspective of EBITDA $=($ EBITDA / Total Assets; while EBITDA $=$ Profit from economic activity + Depreciation + Residual cost of the sold long- term assets and material - Revenue from the sale of long-term assets and material)

$\mathrm{p}=$ probability the company will go bankrupt during the next 12 months

The evaluation is made as follows:

if $1 \geq p \geq 0,50, \quad$ an enterprise is heading to bankruptcy

if $0,50>p \geq 0, \quad$ the enterprise is not heading to bankruptcy

Gulka's model is newer and it is rising in use. Klempaiova, Bohdalova [21] compared it with IN05 and their results showed Gulka's model to be more reliable. Also a comparison of bankruptcy prediction models by Durica, Svabova [18] showed Gulka's model to be the best in comparison with $\mathrm{CH}$-index, G-index and Bonity Index.

\subsection{Other models}

One can find many other foreign models used in articles pertaining to the comparison of bankruptcy prediction models such as Zmijevski, Taffler, Fulmer or Springate model, such as used in Kovacova, Kliestikova [10]. However, these models are not made for the conditions of Slovak republic and due to the extent of this article and their usually bad predictive results when used on Slovak companies, we will not include them in this article.

Also, there are many new models constructed in recent years, however they are usually only proposed by the author of the article and are not used by anyone else. We can say they are expecting acceptance from the scientific community and we will be able to see their use and verification only in a few years time. It can be P' model by Delina, Packová [8] based on 
regression analysis. Gavurova, Janke, Packova and Pridavok [22] also created a new prediction model after analysis of Altman, IN05 and Chen \& Du model using decision tree methods. Another new model by decision tree based model was made by Durica et al. [23,24] Another new model for bankruptcy prediction was proposed by Svabova, Durica, Podhorska [25] using multivariate discriminant analysis. Valaskova, Kliestik, Kovacova [6] proposed a new model using multiple regression analysis. Kovacova, Kliestik [26] proposed models using logistic regression and probit regression.. Mas'ud et al. studied trust.[27]. Svabova and Durica [28] analyzed outliers.

\subsection{Bankruptcy models for non-profit organizations}

During our research for bankruptcy prediction models used in conditions of Slovakia, we identified only use of these models for assessment of financial health of non-profit organizations by Podhorska [29]. She compared 5 bankruptcy prediction models on a sample of 1230 Slovak non-profit organizations. The use of these models for prediction of financial health of non-profit organizations is complicated by the non-profit nature of the organizations, where most models use at least one variable that measures profitability like EBT, EBITDA, that are usually not present in non-profit organizations. We found only one model specificially constructed for non-profit organizations in Slovakia and it used neural networks. [30]

\section{Discussion and conclusion}

In this article, we focused on bankruptcy prediction models in conditions of Slovakia. We enumerated chosen models and commented on their use in the current research. We also identified a great many new bankruptcy prediction models that were developed in recent years. Some of them might be accepted in near future by the scientific community and fulfil the need for a general bankruptcy prediction model tailored to the specific condition of Slovak Republic, as evidenced in Delina, Packová [8] or Kovacova, Kubala, Kliestik et al. [31]. So far, the literature doesn't show a widespread adaptation of any of the new models, neither their testing. It might me a valid question for future research to compare the newly proposed models on current data of Slovak companies.

There is also a present lack of financial distress prediction models for use in non-profit organizations, which might present a gap for potential future research.

This is paper is an outcome of project VEGA: 1/0544/19 Formation of the methodological platform to measure and assess the effectiveness and financial status of non-profit organizations in the Slovak Republic

\section{References}

1. Adamko, P., Chutka, J. (2020). Company bankruptcy and its prediction in conditions of globalization. In T. Kliestik (Eds.), 19th International scientific conference globalization and its socio-economic consequences 2019 - Sustainability in the global-knowledge economy (Article Number 05002). Rajecke Teplice: SHS Web of Conferences.

2. Siekelova, A., Kovalova, E., Ciurlău, C.F. (2019). Prediction financial stability of Romanian production companies through Altman Z-score. Ekonomicko-manazerske spektrum, 13(5), 89-97. 
3. Valaskova, K., Durana, P., Adamko, P., Jaros, J. (2020). Financial Compass for Slovak Enterprises: Modeling Economic Stability of Agricultural Entities. Journal of Risk and Financial Management, 13(5), 92.

4. Kliestik, T., Valaskova, K., Lazaroiu, G., Kovacova, M., Vrbka, J. (2020). Remaining Financially Healthy and Competitive: The Role of Financial Predictors. Journal of Competitiveness, 12(1), 74.

5. Kral, P., Musa, H., Lazaroiu, G., Misankova, M., Vrbka, J. (2018). Comprehensive assessment of the selected indicators of financial analysis in the context of failing companies. Journal of International Studies, 11(4), 282-294.

6. Valaskova, K., Kliestik, T., Kovacova, M. (2018). Management of financial risks in Slovak enterprises using regression analysis. Oeconomia Copernicana, 9(1), 105- 121.

7. Cisko, S., Kliestik, T. (2013). Financial management II. Žilina: EDIS.

8. Delina, R., Packova, M. (2013). Prediction bankruptcy models validation in Slovak business environment. E \& M Ekonomie a management, 16(3), 101-112.

9. Gavurova, B., Packova, M., Misankova, M., Smrcka, L. (2017). Predictive potential and risks of selected bankruptcy prediction models in the Slovak business environment. Journal of Business Economics and Management, 18(6), 1156-1173.

10. Kovacova, M., Kliestikova, J. (2017). Modelling bankruptcy prediction models in Slovak companies. In: Vachal, J., Vochozka, M., Horak, J. (Eds.), Innovative Economic Symposium 2017 (Ies2017): Strategic Partnership in International Trades (Article Number 01013). Ceske Budejovice: SHS Web Conference.

11. Camska, D. (2012). National view of bankruptcy models. In: Loster, T., Pavelka, T. (Eds.), 6th International Days of Statistics and Economics (268-278). Prague: Proceedings Paper.

12. Misankova, M., Zvarikova, K., Kliestikova, J. (2017). Bankruptcy Practice in Countries of Visegrad Four. Economics and Culture, Sciendo, 14,(1), 108-118.

13. Adamko, P., Svabova, L. (2016). Prediction of the risk of bankruptcy of Slovak companies. In: Culik. M., Proceedings of 8th International Scientific Conference Managing and Modelling of Financial Risks (pp. 15-20). Ostrava: Proceedings Paper.

14. Rybarova D., Braunova M., Jantosova L. (2016). Analysis of the Construction Industry in the Slovak Republic by Bankruptcy Model. In: McKenna, B., Ardabili, F.S., Faghih, N.(Eds.), 3rd International Conference on New Challenges in Management and Organization: Organization and Leadership (pp. 298-306 ). U Arab Emirates: Procedia Social and Behavioral Sciences.

15. Neumaier, I., Neumaierovaa, I. (2005). Index IN 05. In: European financial systems (pp. 143-148). Brno: Proceeding.

16. Chrastinova, Z. (1998). Methods of economic creditworthiness evaluation and prediction of financial situation of agricultural holdings. Bratislava: VUEPP.

17. Karpac, D., Bartosova, V. (2020). The verification of prediction and classification ability of selected Slovak prediction models and their emplacement in forecasts of financial health of a company in aspect of globalization. In: Kliestik, T. (Eds.), 19th International Scientific Conference Globalization and Its Socio- Economic Consequences Sustainability in the Global-Knowledge Economy (Article Number 06010). Rajecke Teplice: SHS Web of Conferences.

18. Durica, M., Svabova, L. (2017). Comparative analysis of financial distress prediction models for Slovak companies. In: Slavickova, P. (Eds.), Knowledge for market use: 
people in economics - decisions, behavior and normative models : international scientific conference proceedings (pp. 102-108). Olomouc: Proceedings Paper.

19. Gurcik, L. (2002). G-index - the financial situation prognosis method of agricultural enterprises. Agricultural Economics, 48, 373-378.

20. Gulka, M. (2016). Predictive Model of Corporate Failure in the Slovak Business Environment. Forum Statisticum Slovacum, 12(1), 16-22.

21. Klempaiova, N., Bohdalova, M. (2018). Comparison of Gulka's Model and Model IN05 on Sample of Slovak Industrial Companies. In: Nesleha, J., Hampl, F., Svoboda, M. (Eds.), 15th International Scientific Conference on European Financial Systems 2018 (pp. 259-266). Brno: Proceedings Paper.

22. Gavurova, B., Janke, F., Packova, M., Pridavok, M. (2017). Analysis of impact of using the trend variables on bankruptcy prediction models performance. Journal of Economics, 65(4), 370-383.

23. Durica, M., Frnda, J., Svabova, L. (2019). Decision tree based model of business failure prediction for Polish companies. Oeconomia Copernicana, 10(3), 453-469.

24. Durica, M., Podhorska, I., Durana, P. (2019). Business failure prediction using cartbased model: A case of Slovak companies. Ekonomicko-manazerske spektrum, 13(1), 51-61.

25. Svabova, L., Durica, M., Podhorska, I. (2018). Prediction of Default of Small Companies in the Slovak Republic. Economics and Culture, Sciendo, 15(1), 88.

26. Kovacova, M., Kliestik, T. (2017). Logit and Probit application for the prediction of bankruptcy in Slovak companies. Equilibrium, Quarterly Journal of Economics and Economic Policy, 12(4), 775-791.

27. Mas'ud, A., Manaf, N. A. A., Saad, N. (2019). Trust and power as predictors to tax compliance: Global evidence. Economics and Sociology, 12(2), 192-204.

28. Svabova, L., Durica, M. (2019). Being an outlier: a company non-prosperity sign?. Equilibrium. Quarterly Journal of Economics and Economic Policy, 14(2), 359-375.

29. Podhorska, I. (2020). Evaluation Of The Financial Health Of Non-profit Organizations: A Case Study In The Slovak Republic. In: 55thInternational Scientific Conference on Economic and Social Development (pp. 708-716). Varazdin: Varazdin Development and Entrepreneurship Agency

30. Mazanec, J., Bartosova, V. (2019). The effectiveness of artificial neural networks in prediction of financial vulnerability in Slovak non-profit sector. In: M.L. Simic, B. Crnkovic (Eds). 8th International scientific symposium economy of eastern Croatia vision and growth (pp. 618-633). Osijek: Medunarodni Znanstveni Simpozij Gospodarstvo Istocne Hrvatske-Jucer Danas Sutra.

31. Kovacova, M., Kliestik, T. Kubala, P., Valaskova, K., Radisic, M., Borocki, J. (2018) Banktruptcy models: verifying their validity as a predictor of corporate failure. Polish journal of management studies, 18 (1), 167-179. 